\title{
69-Towards an understanding of post-translation studies: A comparative analysis of cultural transfer in the rewritings of popular literature ${ }^{{ }^{*}}$
}

Dudu ÖZBEK²

\section{Ayşe Selmin SÖYLEMEZ3}

APA: Özbek, D. \& Söylemez, A. S. (2022). Towards an understanding of post-translation studies: A comparative analysis of cultural transfer in the rewritings of popular literature. RumeliDE Dil ve Edebiyat Araştırmaları Dergisi, (26), 1098-1116. DOI: 10.29000/rumelide.1074528.

\begin{abstract}
With the technological developments and the globalization process especially after the 1980 , translations have gained new functions as 'cultural products' that are consumed by the people in various parts of the world. Today, works of popular literature can reach people from diverse cultures in a very short time through translation. These new conditions require the evaluation of the sociocultural functions of these translations with a new perspective in the field of translation studies. In order to analyze these functions of the translated texts, Edwin Gentzler (2017) proposes a framework with the name 'post-translation studies'. Within this framework, Gentzler (2017) draws attention to focus on translation as a form of rewriting and to investigate pre-translation and post-translation conditions in the receiving societies. Gentzler's (2017) approach emphasizes to analyze the translations in their social contexts and to trace the socio-cultural changes that take place in these societies after the translations are put into circulation. As part of 'post-translation studies', this article aims to investigate how Turkish translations of a representative of American popular literature presented American cultural elements in the 1980s and in the 2010s as forms of different rewritings. To this end, Turkish translation of Stephen King's IT in 1987 and its retranslation by the same publisher in 2015 were compared in terms of the representation of the culture specific items. The analyses were based on Pavlovic and Poslek's (1998) categorization of the culture specific items and Aixela's (1996) categories of the translation strategies, which were grouped as being source-oriented and target-oriented on the macro level. Evaluating the results in relation to the socio-cultural context of the receiving society in the 1980 s and the cultural changes that have occurred until the retranslation was published, it was found out that American cultural items in the source text were predominantly translated with target-oriented strategies in the initial translation in 1987 and they were mostly translated with source-oriented strategies in the retranslation in 2015. It was also observed that the familiarity of the items belonging to American culture highly increased for the Turkish readers in the 28-year period as a result of the influence of the source culture.
\end{abstract}

Keywords: Post-translation studies, culture specific items, 1980s, American cultural transfer, rewriting

This article is part of the PhD dissertation in progress at Gazi University, entitled "Cultural and Literary Transfer through Translations of Popular Literature: Turkish Translations of Stephen King's Fiction in the Socio-Cultural Context of the 1980 "

Instructor, Sinop University, Faculty of Education, Department of Foreign Language Education (Sinop, Turkey), dbalozbek@sinop.edu.tr, ORCID ID: oooo-0003-1113-900o [Araştırma makalesi, Makale kayıt tarihi: 31.12.2021-kabul tarihi: 20.02.2022; DOI: 10.29000/rumelide.1074528]

Asst.Prof.Dr., Ankara Hacı Bayram Veli University, Faculty of Letters, Department of Translation and Interpretation (Ankara, Turkey), selminsoylemez@gmail.com, ORCID ID: oooo-0oo1-7231-7523

Adres $\mid$ Address

RumeliDE Dil ve Edebiyat Araştırmaları Dergisi Osmanağa Mahallesi, Mürver Çiçeği Sokak, No:14/8 Kadıköy - İSTANBUL / TÜRKIYE 34714 e-posta: editor@rumelide.com tel: $+905057958124,+902167730616$

RumeliDE Journal of Language and Literature Studies

Osmanağa Mahallesi, Mürver Çiçeği Sokak, No:14/8

Kadıköy - ISTANBUL / TURKEY 34714

e-mail: editor@rumelide.com,

phone: +90 5057958124, +90 2167730616 


\section{Çeviri-sonrası araştırmalara yönelik bir yaklaşım: Popüler edebiyat eserlerinin yeniden yazımlarındaki kültürel aktarım üzerine karşılaştırmalı bir analiz}

$\ddot{O} \mathbf{z}$

1980'li yıllardan itibaren hız kazanan teknolojik gelişmeler ve küreselleşme süreci ile birlikte çeviri eserler, dünyanın farklı bölgelerindeki insanlar tarafından tüketilen 'kültürel ürünler' olarak yeni işlevler kazanmıştır. Günümüzde popüler edebiyat eserleri, çeviri yoluyla farklı kültürlerden insanlara çok kısa sürede ulaşabilmektedir. Bu yeni koşullar, çeviri eserlerin sosyo-kültürel işlevlerinin çeviribilim alanında yeni bir perspektifle değerlendirilmesini gerekli kılmaktadır. Çeviri metinlerin bu türden işlevlerini incelemek amacıyla Edwin Gentzler (2017), 'çeviri-sonrası araştırmalar' başlığı altında bir çerçeve sunmuştur. Bu çerçeve içerisinde Gentzler (2017), çeviriye bir yeniden yazım biçimi olarak odaklanılmasına ve alıcı konumda olan toplumlardaki çeviri-öncesi ve çeviri-sonrası koşulların araştırılmasına dikkat çekmektedir. Gentzler’in (2017) yaklaşımında, çevirilerin kendi toplumsal bağlamı içerisinde analiz edilmesi ve dolaşıma sokulan çeviri eserlerin ardından ne tür sosyo-kültürel değişimlerin yaşandığının araştırılması vurgulanmaktadır. Çevirisonrası araştırmaların bir parçası olarak bu çalışma, Amerikan popüler edebiyatına ait bir eserin Türkçe çevirilerinin 1980’lerde ve 2010'lu yıllarda, Amerikan kültürel unsurlarını farklı yeniden yazım biçimleri olarak nasıl yansıttığını araştırmayı hedeflemektedir. Bu amaçla, çalışma kapsamında Stephen King’in IT isimli romanının 1987'deki ilk çevirisi ile 2015 yılında aynı yayınevi tarafından yayınlanan yeniden çevirisi, kültüre özgü ögelerin aktarılması açısından karşılaştırılmalı olarak incelenmiştir. Yapılan analizlerde Pavlovic ve Poslek’in (1998) kültüre özgü ögelere dair sınıflandırması esas alınmıştır. Bu ögelerin çeviri stratejileri için Aixela'nın (1996) sınıflandırması kullanılmış ve bu sınıflandırmadaki stratejiler makro düzeyde kaynak-odaklı ve hedef-odaklı olmaları bakımından ayrıca gruplandırılmıştır. Elde edilen sonuçlar, hedef kültürün 1980’lerdeki sosyokültürel bağlamı ve romanın yeniden çevirisi yayınlanana kadar geçen sürede gerçekleşen kültürel dönüşümler açısından değerlendirilmiş ve kaynak metinde yer alan Amerikan kültürüne özgü ögelerin 1987'de yayınlanan ilk çeviride ağırlıklı olarak hedef-odaklı stratejiler ile çevrildiği, 2015'te yayınlanan yeniden çeviride ise bu ögeler için çoğunlukla kaynak-odaklı stratejiler kullanıldığı tespit edilmiştir. Buna ek olarak, geçen 28 yıllık sürede kaynak kültürün etkisi ile Amerikan kültürüne özgü ögelerin Türk okuyucusu açısından bilinirliğinin arttığı gözlenmiştir.

Anahtar kelimeler: Çeviri-sonrası araştırmalar, kültüre özgü ögeler, 1980’ler, Amerikan kültür aktarımı, yeniden yazım

\section{Introduction}

Many studies have focused on the socio-cultural functions of the translational activities in the field of translation studies so far (Bassnett, 1980, 1998, 2007; Even-Zohar, 1979, 1990, 2002; Hermans, 1985; Lefevere, 1992, 1998; Toury, 1978/2004, 1985, 1995, 2005; Venuti, 1995, 1998, 2012). These studies and discussions led to the cultural turn in the field during the 1980 s and the sociological turn in more recent years (Snell-Hornby, 2006). Through the contributions of these studies, today it is widely accepted that translations are not only linguistic texts to convey messages of the original work but also cultural tools which have various influences on the socio-cultural, historical and political contexts of the receiving societies.

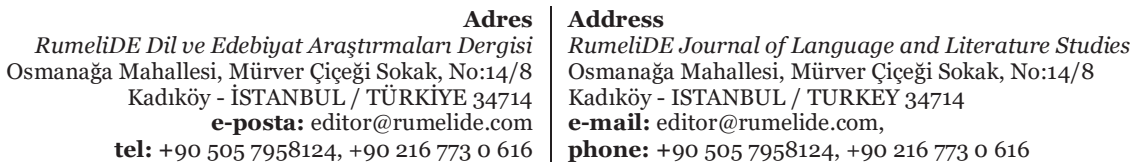

RumeliDE Dil ve Edebiyat Araştırmaları Dergisi Kadıköy - İSTANBUL / TÜRKIYE 34714 tel: +90 $5057958124,+902167730616$

phone: +90 505 7958124, +90 2167730616 
With the influence of globalization and the technological developments especially after the 1980 s, however, these socio-cultural functions of the translated texts have taken many other forms within the dynamics of the modern societies. Today, it is possible to claim that translations have a greater capacity to reach people in many distant places of the world in a shorter time and produce literary and cultural influences in more complicated ways. As the production and the distribution of the translated texts become more and more dependent on the mechanisms of the global markets, it becomes a necessity to evaluate translations "as commodities that are produced and consumed according to the rules of a hierarchically structured market" (Baumgarten \& Cornellà-Detrell, 2018, p.1). Thus, rapid changes in the production and distribution of the texts with the help of the advanced technology requires to consider translations as cultural products more than being mere tools of communication and crosscultural exchange.

Consequently, while cultural approaches in translation studies so far have contributed a lot to analyze translations in relation to the cultural systems rather than focusing on their linguistic properties independently, the globalization process in the 21st century requires to evaluate the influences of these texts that circulate around the world as cultural products to reach many people from diverse cultural backgrounds. What do these translations convey to different parts of the world as cultural products that are consumed by the readers in these receiving societies? To answer such questions, Edwin Gentzler (2017) proposes to conduct analyses as part of "post-translation studies" and he suggests focusing on the post-translation effects of the texts in the receiving societies as well as a comparison with the conditions before the translation appeared. Although there have been great developments in the field of translation studies in the last decades, Gentzler (2017) finds the field "as still restricted, primarily focused on written texts and two-way comparisons, and neglecting pre- and post-translation conditions and effects" (p.2).

In his work Translation and Rewriting in the Age of Post-Translation Studies, Gentzler (2017) indicates that translation activities have reached to a new level due to the globalization process and new technological devices. He points out that during this process, rewritings of the texts circulate around the world easily with the help of the new forms of media like iPads, iPhones, YouTube and social networking sites. As Lefevere (1992) states, translation is actually a rewriting of the original text and each rewriting acts as a form of manipulation that will function in a given society in a different way (p.vii). It is, therefore, noteworthy to analyze these rewritings and their influences on the societies as part of translation studies. According to Gentzler (2017), these social, cultural and political effects of the translations as rewritings can be studied within the framework of post-translation studies. With the term 'post-translation studies', he suggests that "to measure the success or failure of the ideas or the aesthetics of a translation, one has to look beyond translation and to begin to examine the cultural changes that take place after the translation, hence the move toward a post-translation analysis" (p.3). In this way, it can be possible to focus on the socio-cultural functions and influences of the translations more than a comparison of the source text and its translated form.

To conduct this kind of socio-cultural research, Gentzler (2017) proposes to "analyze both the initial reception of the translated text and the post-translation repercussions generated in the receiving culture over subsequent years" (p.3). What kind of cultural and literary changes occurred in the target culture after the introduction of these translations? If new literary forms were introduced to a society through translated texts, did they cause any changes in the conventions that the original writers followed in that society during the next decades? If new concepts and ideas were conveyed to a culture with the help of translations, did they lead to any changes in the politics, art, architecture or way of living in that cultural

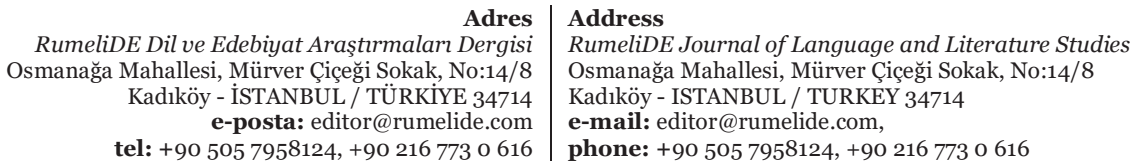


environment? Post-translation studies aims to find answers to such questions through a comparison of the post-translation repercussions with the pre-translation conditions in the receiving societies.

In line with this perspective, this article introduces a post-translation analysis of an example of American popular literature by focusing on its initial translation and the retranslation in the changing sociocultural contexts. The underlying purpose in focusing on an example of popular literature is that these novels are amenable to a post-translation analysis as these kinds of literary works circulate through new media channels in the form of films, TV series, shows, music or even games and they reach more and more people in the form of rewritings. As Pawling (1984) states, "to understand popular fiction is to examine it as a form of cultural production and as a process of meaning creation which offers a particular way of thinking and feeling about one's relationship to oneself, to others, and to society as a whole" (p.4). As a consequence, it can be claimed that these studies on popular literature provide significant data in relation to the socio-cultural context of the societies and the expectations of the readers. Reaching people from various cultural backgrounds through translation, popular literature can trigger literary and cultural influences as being not only literary texts but also cultural products that are conveyed to the receiving societies. Thus, post-translation studies are particularly significant to understand the influences of such popular literary works by examining both pre-translation and post-translation conditions in the societies that they appear.

As part of these studies, in this article, Turkish translation of Stephen King's IT in 1987 and its retranslation by the same publisher in 2015 will be analyzed particularly in relation to the representation of the American cultural items in the original book. Data collection and categorization will be based on Pavlovic and Poslek's (1998) categorization of the culture specific items and Aixela's (1996) categories of the translation strategies. Reflecting the view of post-translation studies, the analyses will be carried out by focusing on the initial translation in the socio-cultural context of the 1980 s and its retranslation in 2015 with the aim of tracing the cultural changes that have occurred in the receiving society throughout those years.

\section{Socio-Cultural Context During the Initial Translation: The $1980 \mathrm{~s}$}

In the framework that is proposed for the post-translation studies, it is significant to analyze the pretranslation conditions in the target society. Such an analysis enables the scholars to elaborate on the changes that have taken place after the translation was published. As the initial translation in the case study of this analysis belongs to the time period of the $198 \mathrm{os}$, it is beneficial to consider the socio-cultural background of these times in order to understand the underlying factors of the translational decisions.

The 1980 s is a period which signifies important changes not only in Turkey but also in many different parts of the world since those years are characterized by rapid technological developments, neoliberal policies and globalization as the determining factors in various areas (Boughton, 2001; Conversi, 2010; Sassen, 1996; Thompson, 2007). It can be stated that due to the fast speed of innovations specifically in the information technologies, the effects of globalization started to be observed in many countries particularly starting from the second half of the 1980 s.

Strange (1996) defines globalization as a term referring to anything from the Internet to a hamburger and "all too often, it is a polite euphemism for the continuing Americanisation of consumer tastes and cultural practices" (p.xiii). The reason for this kind of a relation between globalization and Americanisation can be explained with the acceleration in the distribution of the American cultural

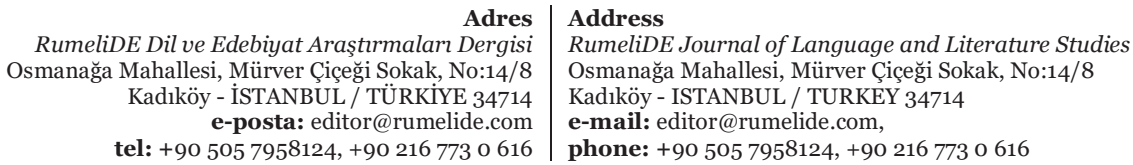


elements to various countries during the 1980s. In this period, American brands and cultural products could reach many people all over the world with the help of the changing dynamics of the international markets and the mass media more than it was observed in the previous time periods in history. Since 1980 s, international media industries have had enormous opportunities to distribute American cultural products in the form of movies, popular books and music videos (Holt, 2001).

According to Bolton \& Olsson (2010), after the economic boom in the 1980 s and the political changes in many countries, "the aesthetics of premier American brands are globally celebrated and buttressed to varying degrees by shared domains of popular culture, from cinema to fashion to hip-hop. This, in turn, has favored the spread of American English-alongside burgers, blue jeans and their accompanying aesthetics" (p.15). Turkey is one of these countries in which American brands and cultural products started to be consumed in an increasing number especially after the economic and political shifts that occurred in 1980. As Güzelsarı (2007) explains, "in the 1980s, Turkey adopted a new structure which depended on exportation and which aimed to pull foreign capital to the country in a way that would allow it to integrate with the global market" (p.64). As a result of the requirements of the international trading, developing countries like Turkey had to be more open to the foreign markets. In this sense, "the year 1980, signifies an outstanding transformation in terms of Turkey's political and economic history" (Güzelsar1,2007, p.64). Therefore, it is plausible to argue that especially after the coup de'tat in 1980, Turkey experienced many shifts in terms of its economic and political orientation which had crucial effects on the socio-cultural formation of the country at the same time. Köse (2016) explains these interrelated changes as "the new economic policies that were put into action after 1980 in Turkey not only transformed the economic activities but also led to the formation of a different society by changing the socio-cultural values, ethical beliefs and the daily life practices of the people" (p.116).

Considering these developments, 1980 os in Turkey can be characterized by the foreign products that were presented for people's consumption through the advertisements in the newspapers and on TV as a result of the free market policies. Particularly with 'January 24 Decisions' in 1980, a more liberal economy policy and free market practices were adopted and this allowed many foreign brands to be sold easily following the changes in import regulations (Gökçen,2013; Güzelsarı,2007; Köse,2016; Sever,2019; Sönmez,2008; Tellan,2008; Uçkaç, 2010). The policies that were adopted during those years can be symbolized with the American Cross pen, the Turkish prime minister of the time held while he was giving his 'address to the nation' speeches on TV. People were encouraged to consume more than ever and products of foreign brands like Levi's or Marlboro that were not sold in the country in the past became a part of many people's lives.

Together with the availability of those foreign products, American culture and lifestyle became more and more influential on the daily life of the people during this period through mass media, popular journals and books. It can be claimed that the increasing consumerism in the society and popularity of foreign products in the 1980 s went hand in hand with the increasing influence of the American lifestyle in Turkey (Bali,2002; Büken,2001; Sever,2019; Şahin,2005).

Due to these transformations in the politics, economic activities and social structure of the country, Turkey became more and more integrated to the global network of cultural practices. In her book Vitrinde Yaşamak: 1980'lerin Kültürel İklimi, Gürbilek (2016) states that in the 1980s, "culture became dependent on the markets at such a level that was not seen before, advertising put infinite number of images into motion and a new kind of public opinion and language of news emerged with the publication of popular news journals" (p.21). As a consequence, a new cultural context was beginning to be formed

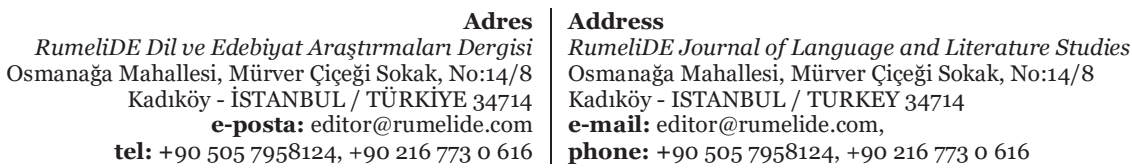


through cultural products such as films, TV programmes, music videos, popular journals and books whose production and distribution were highly dependent on the mechanisms of the market economy.

In the light of these socio-cultural developments to display the pre-translation conditions, this article focuses on how translations of popular literature books functioned to represent the American cultural items to the Turkish readers during the 1980 os. It also aims to trace the cultural changes that have occurred in the receiving society since those years through a comparison of the first translation with the retranslation as a post-translation analysis. For these purposes, Stephen King's IT was selected as a case study since King's books are among the most translated books in the world (Index Translationum, 2019) and they reach many people in the form of rewritings like films, TV series and games. In addition, IT was retranslated into Turkish nearly 30 years after the initial translation of the book by the same publisher. A comparison of these two different translations at different time periods can yield interesting results in terms of the changing expectations of the Turkish readers in time.

\section{A Comparative Analysis of the Cultural Transfer in the Initial Translation (1987) and the Retranslation (2015) of Stephen King's IT by Altın Kitaplar}

$I T$ is considered to be one of the most well-known and successful books of Stephen King together with The Stand and The Dark Tower series (Wood,2011; Spignesi,2001). The novel was published in 1986 and since its publication, it has had different adaptations on TV and cinema. Its evil character Pennywise the Dancing Clown has long been an icon of horror in pop culture.

The novel was first translated into Turkish by Gönül Suveren in 1987 and it was retranslated by Oya Alpar in 2015. Both the initial translation and the retranslation were published by Altı Kitaplar Publishing House. While the first translation was a shortened version of the novel with many omissions, retranslation of the book contained the full text. Through a comparison of these two different translations by the same publisher in terms of the representation of the cultural items, it is aimed to find out how the source culture became more familiar for the readers in time as reflected in the translation strategies that were used by the translators.

In order to evaluate such representations of the source culture, the study focused on culture specific items (CSIs) that occurred in the original text and how they were translated in the initial translation and the retranslation. Pavlovic and Poslek (1998)'s definition for the CSIs was used while detecting and categorizing the items in the original book. In their study, they defined CSIs as "elements and phenomena which do not exist or are different in the target culture, and for which there are no adequate target language equivalents" (p.159). Their categorization of such items was also used for grouping the data that was obtained from the book, which will be explained in the following sections.

\subsection{Methodology and Data Collection Procedures}

The study is based on a descriptive analysis of the data that was collected from the Turkish translations of IT. The data was quantified numerically in percentages to see the distribution of the strategies and then evaluated in a descriptive way to understand the differences in the translational decisions in different time periods.

First, the culture specific items (CSIs) were detected in the original book and were categorized manually according to the model that was proposed by Pavlovic and Poslek (1998). The model which was developed by Pavlovic and Poslek (1998) was used by adding an extra category for this study to involve 
all the CSIs that were encountered in the source text. Then, their translation strategies were categorized by using Aixela's (1996) categories of the translation strategies for the CSIs. Two experts from the field categorized the items for interrater reliability to reach the final list of the data in relevant categories. The categorization focused on types and recurring items were not given new numbers.

As a result of a comparative analysis between the initial translation and the retranslation, an evaluation was made in relation to the representation of American culture to the target readers in 1987 and in 2015 based on the translations' orientation as being source-oriented and target-oriented. In this way, the study combined the quantitative data obtained from the two translations with a descriptive methodology to understand the socio-cultural changes that occurred in the receiving society as a post-translation analysis.

\subsection{Data Analysis and Discussion}

The reason for using Pavlovic and Poslek's (1998) model for detecting and categorizing the CSIs is that the categories of this model are defined well with many examples and it covers a wide range of cultural areas to group the items that were detected in the translations. In addition, in their study of the CSIs, there is a particular emphasis on the changing socio-cultural contexts of Croatia as a result of its shift to a market economy. Such a socio-cultural background was thought to be more appropriate for the purpose of this article.

Pavlovic and Poslek's (1998) categorization model for grouping the CSIs contained 13 categories consisting of 'ecology', 'everyday life', 'material culture', 'history', 'religion', 'economy', 'political and administrative functions and institutions', 'the armed forces', 'education', 'forms of address', 'gestures and habits', 'work', and 'leisure and entertainment'. While collecting the data for this study, however, some CSIs about the description of people were also detected in the original book. Thus, the category of 'description of people' was added to the original model that was proposed by Pavlovic and Poslek (1998) in order to include such items in the analyses, as well.

A total of 1452 CSIs were detected in IT and 396 of these items belonged to the category of 'leisure and entertainment'. This category has the highest number of CSIs and it is related to the entertainment activities and places, sports, TV shows, games, films, names of the famous TV personalities, musicians, etc. This group of items indicates $27.27 \%$ of the total number of the CSIs in the book. The second cultural category with the highest number of items is 'everyday life' including 348 items. This category is about the everyday life practices of the people in the source culture like housing, food, transportation, public services, etc. These items make up $23.97 \%$ of the total number of the CSIs. As the third highest category, 'material culture' involves products, brands and trademarks that are well-known in the source culture. 344 items were recorded about the material culture and this number accounts for $23.69 \%$ of the total number of the CSIs in the original book. Distribution of the CSIs and their percentages can be seen in Table. 1 and Figure. 1 below:

Table.1. Distribution of The Culture Specific Items in Stephen King's IT (1986)

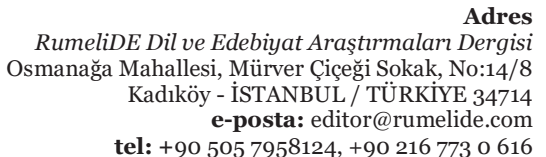

dres isi 8
Address

RumeliDE Journal of Language and Literature Studies

Osmanağa Mahallesi, Mürver Çiçeği Sokak, No:14/8

Kadıköy - ISTANBUL / TURKEY 34714

e-mail: editor@rumelide.com

phone: +90 5057958124, +902167730616 
RumeliDE Dil ve Edebiyat Araştırmaları Dergisi 2022.26 (Şubat)/ 1105 Çeviri-sonrası araştırmalara yönelik bir yaklaşım: Popüler edebiyat eserlerinin yeniden yazımlarındaki kültürel aktarım üzerine karşılaştırmalı bir analiz / D. Özbek \& A. S. Söylemez (1098-1116. s.)

\begin{tabular}{|l|l|l|}
\hline Category & Number of the CSIs & Percentage \\
\hline Ecology & 14 & $(0.97 \%)$ \\
\hline Every Day Life & 348 & $(23.97 \%)$ \\
\hline Material Culture & 344 & $(23.69 \%)$ \\
\hline History & 147 & $(10.12 \%)$ \\
\hline Religion & 64 & $(4.41 \%)$ \\
\hline Economy & 14 & $(0.96 \%)$ \\
\hline $\begin{array}{l}\text { Political And Administrative } \\
\text { Functions And Institutions }\end{array}$ & 23 & $(1.58 \%)$ \\
\hline The Armed Forces & 27 & $(1.86 \%)$ \\
\hline Education & 30 & $(2.07 \%)$ \\
\hline Forms Of Address & 6 & $(0.41 \%)$ \\
\hline Gestures And Habits & 15 & $(1.03 \%)$ \\
\hline Work & 2 & $(0.14 \%)$ \\
\hline Leisure And Entertainment & 396 & $(27.27 \%)$ \\
\hline Description Of People & 22 & $(1.52 \%)$ \\
\hline & & \\
\hline $\begin{array}{l}\text { TOTAL NUMBER OF THE } \\
\text { CSIs }\end{array}$ & $\mathbf{1 4 5 2}$ & \\
\hline
\end{tabular}

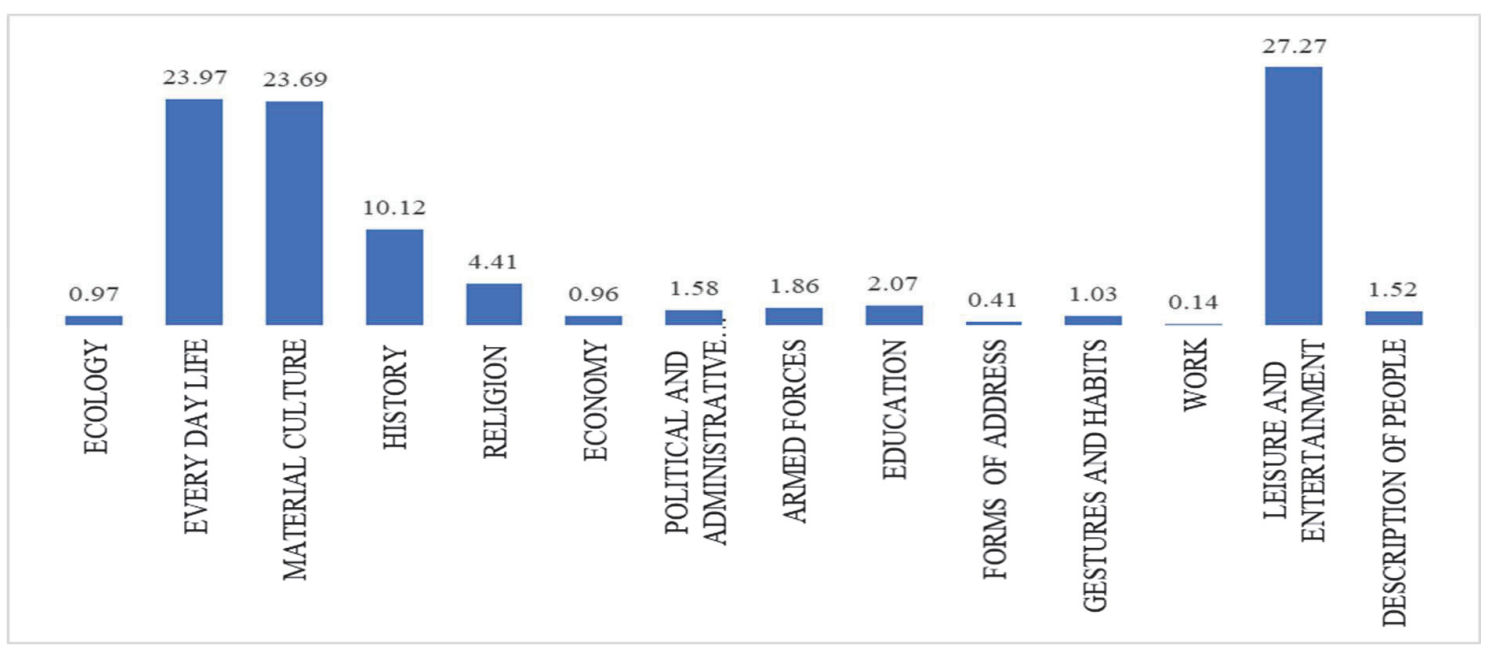

Figure.1. Percentages of The Culture Specific Items in Stephen King's IT (1986)

As can be seen in Table.1 and Figure.1, CSIs that were detected in the book IT mostly belonged to the categories of leisure and entertainment, everyday life and material culture.

After the categorization of the CSIs, distribution of the translation strategies for these CSIs were evaluated according to Aixela's (1996) categorization for the strategies. These categories of translation strategies are 'repetition', 'orthographic adaptation', 'linguistic (non-cultural) translation', 'extratextual

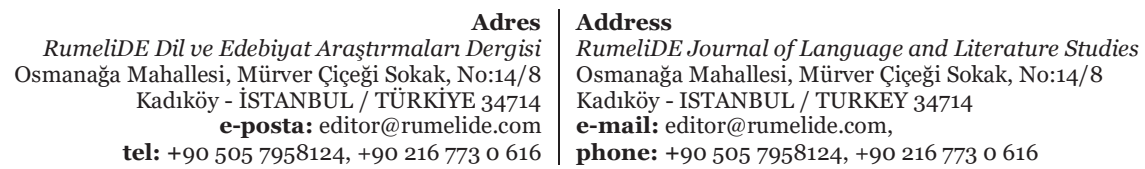


Towards an understanding of post-translation studies: A comparative analysis of cultural transfer in the rewritings of popular literature / D. Özbek \& A. S. Söylemez (pp. 1098-1116)

gloss', ‘intratextual gloss', ‘synonymy', 'limited universalization', 'absolute universalization', 'naturalization', 'deletion' and 'autonomous creation'.

In repetition, the translator preserves the original reference and in orthographic adaptation, $\mathrm{s} /$ he adapts the item according to the morphological or phonological system of the target language only in terms of its form. In linguistic translation, the translator applies a non-cultural, literal translation strategy for the item mostly by using a target language version in the intertextual corpus of the translated texts in that language. When extratextual gloss is used, the translator provides an explanation of the item for the readers as a footnote or in glossary whereas in intratextual gloss, the explanation is given within the text.

In addition to these, in the case of synonymy, the translator uses a synonym of the item on the stylistic grounds mainly for the aim of avoiding repetition. Besides, limited universalization is used when the translator replaces the CSI with an item still belonging to the source culture but more well-known for the readers in the target culture. On the other hand, if the item is replaced with a general term as a neutral reference, then, the translator uses absolute universalization.

As another substitution strategy, the translator uses a similar item that is used in the target culture and thus, applies cultural substitution, which is called naturalization in Aixela's (1996) categorization. Moreover, the translator can use deletion as a strategy to overcome translation difficulties of the CSIs or $\mathrm{s} /$ he can add nonexistent information to the text by using the strategy of autonomous creation.

These strategies that were mentioned by Aixela (1996) were also categorized for this study in terms of their being source-oriented and target-oriented. It was considered that if the strategy conserves the 'foreign essence' of the item without any changes or additions to its meaning, it is labelled as a sourceoriented strategy. If the item is translated in a way to interfere with its original meaning in order to make it more comprehensible for the readers, it is labelled as a target-oriented strategy.

Table. 2. Categorization of Aixela's (1996) Translation Strategies

\begin{tabular}{|c|c|}
\hline Translation Strategy & Orientation \\
\hline Repetition & Source-oriented \\
\hline Orthographic Adaptation & Source-oriented \\
\hline Linguistic (non-cultural) Translation & Source-oriented \\
\hline Extratextual gloss & Target-oriented \\
\hline Intratextual gloss & Target-oriented \\
\hline Synonymy & Target-oriented \\
\hline Limited universalization & Target-oriented \\
\hline Absolute universalization & Target-oriented \\
\hline Naturalization & Target-oriented \\
\hline $\begin{array}{r}\text { Adres } \\
\text { RumeliDE Dil ve Edebiyat Arașttrmaları Dergisi } \\
\text { Osmanağa Mahallesi, Mürver Ciçĕi Sokak, No:14/8 } \\
\text { Kadıköy - İSTANBUL / TÜRKiYE 34714 } \\
\text { e-posta: editor@rumelide.com } \\
\text { tel: }+905057958124,+90216773 \text { o } 616\end{array}$ & $\begin{array}{l}\text { Address } \\
\text { RumeliDE Journal of Language and Literature Studies } \\
\text { Osmanağa Mahallesi, Mürver Ciceği Sokak, No:14/8 } \\
\text { Kadıköy - ISTANBUL / TURKEY } 34714 \\
\text { e-mail: editor@rumelide.com, } \\
\text { phone: +90 } 5057958124,+90216773 \text { o } 616\end{array}$ \\
\hline
\end{tabular}


RumeliDE Dil ve Edebiyat Araştırmaları Dergisi 2022.26 (Şubat)/ 1107 Çeviri-sonrası araştırmalara yönelik bir yaklaşım: Popüler edebiyat eserlerinin yeniden yazımlarındaki kültürel aktarım üzerine karşlaştırmalı bir analiz / D. Özbek \& A. S. Söylemez (1098-1116. s.)

\begin{tabular}{|l|l|}
\hline Deletion & Target-oriented \\
\hline Autonomous creation & Target-oriented \\
\hline
\end{tabular}

When these translation strategies were evaluated in the first translation and the retranslation of $I T$ according to the 14 cultural areas that were defined, it was found out that CSIs were predominantly translated with target-oriented strategies in the initial translation while they were translated mostly with the source-oriented strategies in the retranslation of the novel.

In total, $91.18 \%$ of the items were translated with target-oriented strategies in the first translation of the book and only $8.82 \%$ of them were translated with source-oriented ones. However, it should also be mentioned that these target-oriented strategies involved deletion which was highly used in that initial translation as it is actually a shortened version of the original book. $68.60 \%$ of the items were not reflected in this translation at all since they appeared in the omitted parts and paragraphs of the original book or they were omitted as individual items in the sentences during the translation. In order to see what kind of strategies were adopted for the CSIs that were translated, an additional calculation was made without considering deletion. In this case, the result did not change. It was found out that even if the omitted items were not taken into consideration, the percentage of the target-oriented strategies was much higher in the initial translation of the book. In this case, $71.93 \%$ of the translated items were represented by using the target-oriented strategies while source-oriented strategies were used for $28.07 \%$ of them.

In contrast, in the retranslation, $67.97 \%$ of the items were translated with source-oriented strategies, particularly with repetition while $32.03 \%$ of them were translated with target-oriented ones. It was observed that the most frequently used strategy was repetition in the retranslation as it was used for $50.21 \%$ of the CSIs in the book.

The difference in the representation of the CSIs in the first translation and the retranslation of $I T$ is illustrated in Figure.2. below:

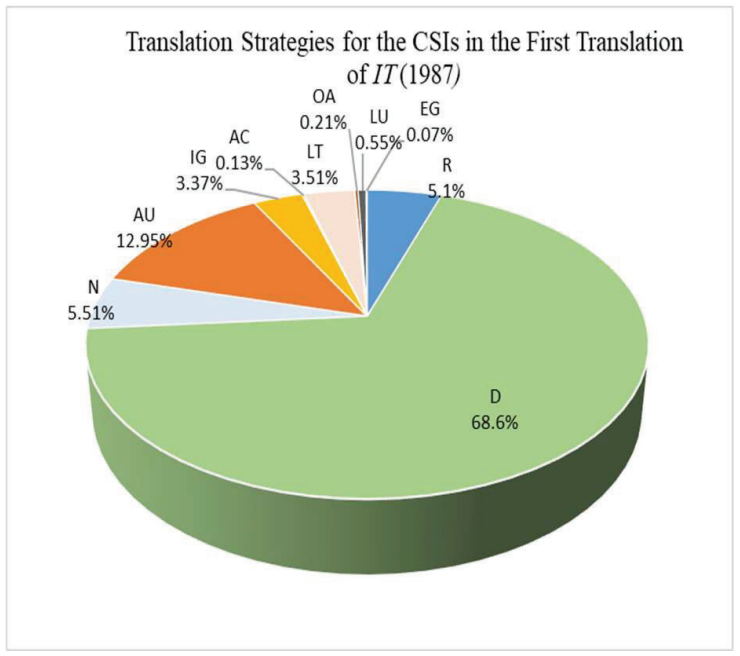

Adres
RumeliDE Dil ve Edebiyat Araştırmaları Dergisi Osmanağa Mahallesi, Mürver Çiçeği Sokak, No:14/8 Kadıköy - İSTANBUL / TÜRKIYE 34714 tel: $+905057958124,+902167730616$

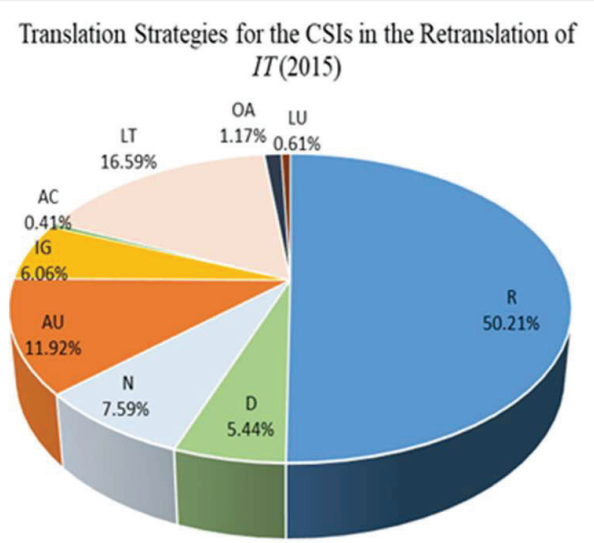

Address

RumeliDE Journal of Language and Literature Studies

Osmanağa Mahallesi, Mürver Çiçeği Sokak, No:14/8

Kadıköy - ISTANBUL / TURKEY 34714

e-mail: editor@rumelide.com,

phone: +90 $5057958124,+902167730616$ 
*R: Repetition; OA: Orthographic Adaptation; LT: Linguistic (non-cultural) Translation; EG: Extratextual Gloss; IG: Intratextual Gloss; LU: Limited Universalization; AU: Absolute Universalization; N: Naturalization; D: Deletion; AC: Autonomous Creation

Figure.2. Translation Strategies for the CSIs in the First Translation and the Retranslation of IT in 1987 and 2015

In addition to this quantitative data, some examples about the differences in the predominantly used strategies for the CSIs are presented below as a descriptive evaluation. This evaluation provides insights to understand what type of cultural items were translated with which strategies and how the strategies changed in time with the influence of the source culture. Within the scope of this article, examples about the three categories with the highest number of items will be given; that is, 'leisure and entertainment', 'material culture' and 'everyday life'. In addition, two examples will be presented about the category of 'education' in order to reveal the differences in the educational systems of the source culture and the target culture and how these differences were handled by the translators in different time periods.

Table.3. Examples about The Category of 'Leisure and Entertainment'

\begin{tabular}{|c|c|c|c|}
\hline & ST & TT1 & TT2 \\
\hline Example 1 & $\begin{array}{l}\text { "That's Mall Road these } \\
\text { days. We've got the third- } \\
\text { biggest shopping mall in } \\
\text { the state out there. Forty- } \\
\text { eight Different Merchants } \\
\text { Under One Roof for Your } \\
\text { Shopping Convenience." } \\
\text { "Sounds really A-A-American, } \\
\text { all right." } \\
\text { "Bill?” (King,1986/2017, p. } \\
\text { 487) }\end{array}$ & $\begin{array}{l}\text { “Orası artık Çarşı Yolu. } \\
\text { Eyaletin en büyük } \\
\text { çarşılarından biri yapıldı } \\
\text { oraya.” } \\
\text { "Y-y-ya...” } \\
\text { "Bill?” (King,1986/ } \\
\text { Suveren,1987 (trans.),p.202) }\end{array}$ & $\begin{array}{l}\text { “Orası artık AVM Yolu. } \\
\text { Eyaletteki üçüncü en büyük } \\
\text { alışveriş merkezi orada. } \\
\text { Aynı çatının altında } \\
\text { toplanmış kırk sekiz marka. } \\
\text { "Alışveriş zevkini ayağınıza } \\
\text { getirdik,' diyorlar” } \\
\text { "Kulağa sapına kadar A... } \\
\text { A..Amerikan geliyor.” } \\
\text { "Bill?” (King,1986/ } \\
\text { Alpar,2015 (trans.), p.523) }\end{array}$ \\
\hline Example 2 & $\begin{array}{l}\text { "What the hell. It can't be any } \\
\text { worse than interviewing } \\
\text { Ozzy Osbourne" (King, } \\
\text { 1986/2017,p. 536) }\end{array}$ & $\begin{array}{l}\text { "Ne yapalım? Bazı tanınmış } \\
\text { yıldızlarla röportaj } \\
\text { yapmaktan daha zor olamaz } \\
\text { ya!" (King, 1986/Suveren, } 1987 \\
\text { (trans.),p.224) }\end{array}$ & $\begin{array}{l}\text { "Ne olacaksa olsun. Ozzy } \\
\text { Osbourne ile röportaj } \\
\text { yapmaktan kötü olamaz ya? } \\
\text { (King, 1986/Alpar, } 2015 \\
\text { (trans.),p.575) }\end{array}$ \\
\hline
\end{tabular}

These examples are about the translation of the CSIs in the category of leisure and entertainment, which has the highest number of items among the cultural categories. This category includes items about sports, entertainment places and activities, TV shows, movies, games, songs, the names of the famous actors/actresses, etc. In the first example, it can be seen that while "shopping mall" was translated as "çarş" in the initial translation, it was translated as "AVM" and "alışveriş merkezi" in the retranslation. This difference in the translation strategies indicates certain changes in the Turkish people's shopping habits and the influence of the source culture in time in terms of their lifestyle. In the 1980s, shopping malls were not widespread in Turkey and it was not a well-known concept for the readers. The first shopping mall was opened in 1988 with the support of the prime minister and they have become increasingly popular places to do shopping and to spend time for the people since those years (Zeytinoğlu, Uydaci, Akay, Değerli \&Yerden, 2016). Today, it is possible to see many shopping malls in the country especially in big cities. Thus, the first translator of the novel preferred to use the word "çarşı" for the translation of "shopping mall" as the readers were not so familiar with the concept of the shopping mall that is described in the source text. Since it is implied in the text that the concept of the shopping mall includes stores selling products of different brands and this way of consumerism is a reflection of American culture, the word "çarşı" does not actually convey the concept's full reference.

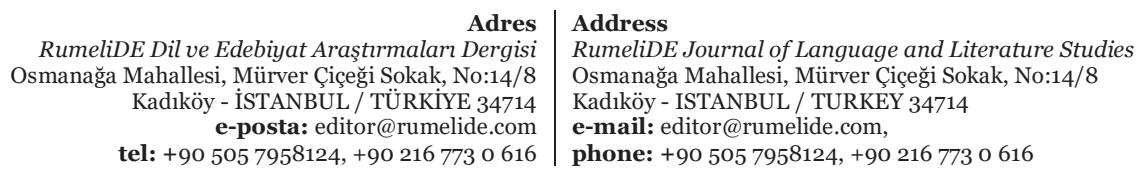


However, retranslator of the book used a direct reference for the word with it is well known form as AVM in the receiving society today.

There were similar examples in relation to such translation differences between the first translation and the retranslation of the book and the familiarity of the names and the items was a significant factor to understand the translators' decisions in different time periods. As can be seen in the second example in Table. 3, Ozzy Osbourne was translated in general terms as "bazı tanınmış ylldılar" (some well-known stars) in the first translation without mentioning the singer's name and it was translated as Ozzy Osbourne without making any changes in the retranslation. On the other hand, it was also detected that in the initial translation, the names of some famous singers like Elvis Presley, Madonna and Michael Jackson were mentioned directly with the strategy of repetition. Such examples show that the translators preferred to use source-oriented strategies like repetition, linguistic translation and orthographic adaptation when the item is familiar for the readers. However, for the unfamiliar items, they mostly used target-oriented strategies to increase their comprehensibility. Thus, increasing use of the sourceoriented strategies for the CSIs in the retranslation signals the increasing familiarity of the American cultural elements for the Turkish readers. Source-oriented strategies were used only for about $8 \%$ of the total items in this group in the initial translation and most of the items belonging to this cultural category were not reflected in the translation at all as they appeared in the omitted parts of the original book or they were deleted as individual items while translating the sentences. Nevertheless, even if the deleted items are not taken into consideration, $50 \%$ of the translated items in this group were represented with these source-oriented strategies in the initial translation while the percentage of the source-oriented strategies for this group is $81.31 \%$ in the retranslation.

Table.4. Examples about The Category of 'Everyday Life'

\begin{tabular}{|c|c|c|c|}
\hline & ST & TT1 & TT2 \\
\hline Example 1 & $\begin{array}{l}\text { A dried maroon stain colored } \\
\text { the thickness of the pages in } \\
\text { the middle of the book. It } \\
\text { could have been old } \\
\text { ketchup. } \\
\text { (King,1986/2017,p.345) }\end{array}$ & $\begin{array}{l}\text { Albümün yan tarafinda koyu } \\
\text { kırmızı bir leke vardı. Ama } \\
\text { tabii bu salça da olabilirdi } \\
\text { (King,1986/Suveren,1987 } \\
\text { (trans.),p.148) }\end{array}$ & $\begin{array}{l}\text { Kitabın ortasındaki } \\
\text { sayfalarda, kahverengiye } \\
\text { çalan kırmızı bir leke vardı. } \\
\text { Kurumuş ketçap olabilirdi } \\
\text { elbette... } \\
\text { (King,1986/Alpar,2015 } \\
\text { (trans.),p.376) }\end{array}$ \\
\hline Example 2 & $\begin{array}{l}\text { Beverly Marsh had shown up } \\
\text { around three o'clock, wearing } \\
\text { faded jeans and toting a } \\
\text { very old Daisy air rifle that } \\
\text { had lost most of its pop... } \\
\text { (King, 1986/2017,p.373) }\end{array}$ & $\begin{array}{l}\text { Beverly o gün saat üçe doğru, } \\
\text { elinde bir eski havalı tüfekle } \\
\text { çlkagelmişti (King, 1986/ } \\
\text { Suveren, } 1987 \text { (trans.), p.158) }\end{array}$ & $\begin{array}{l}\text { Saat üçe doğru, taşlanmış } \\
\text { kotu ve Daisy havalı } \\
\text { tüfeğiyle Beverly Marsh da } \\
\text { onlara katılmıştı (King, } \\
\text { 1986/Alpar, 2015 } \\
\text { (trans.),p.406) }\end{array}$ \\
\hline
\end{tabular}

These excerpts provide examples about the translation of the CSIs belonging to the category of everyday life. This category involves items in relation to the everyday practices of the people such as meals, clothes, and transportation services in the source culture and it has the second highest number of CSIs among the cultural categories. These extracts indicate interesting findings which show the influence of the source culture on the receiving society in time.

In the first extract, it is seen that the word "ketchup" was translated as "salça" in the initial translation which actually refers to "tomatoe paste". By substituting the original item with a culturally similar one, the translator applied the strategy of naturalization in this case. The most probable reason for the use of this strategy is that the item was not known by the Turkish readers during the 1980s. Ketchup has been

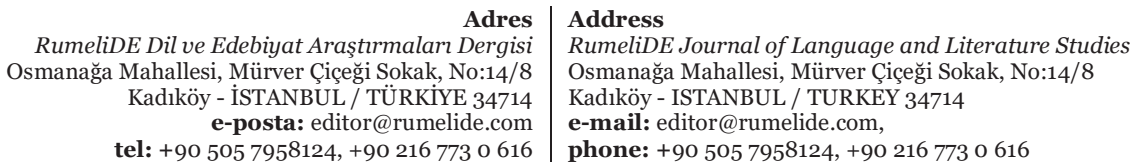


widely consumed in the US since its first production by Heinz company and it has become a representative of the American way of living with the fast food consumption. Although it was not a wellknown product for the Turkish people before the 1980s, it started to be consumed especially after the opening of the famous fast food restaurants like McDonalds and Burger King in the country towards the end of the 1980s. Today it has become a well-known item for the readers and thus, the retranslator did not need to apply a cultural substitution and translated it as "ketçap".

Similarly, in the second example, the item 'faded jeans' was translated as 'taşlanmış kot' by the retranslator while it was totally deleted in the initial translation of the book. The reason for this difference in translation strategies can be explained with the familiarity of the item for the readers at different times. While faded jeans were not well-known in Turkey during the 1980 s, they are widely consumed by Turkish people in recent years. Evidently, these examples indicate how the changing sociocultural conditions and the changes in the expectations of the readers can influence the translation strategies that are used by the translators in different time periods.

As illustrated in the examples above, familiarity of the CSI for the readers is a determining factor for the translators while choosing the strategy that they will use. For instance, it was observed that both of the translators used target-oriented strategies for the translation of "giblet gravy" as it is still an unfamiliar item for many readers in Turkey. The first translator translated it as "koyu salça" by using the strategy of naturalization and the retranslator used a general term for the translation and translated it as "sos".

As a result, for the category of everyday life, it can be concluded that the familiarity of such items for Turkish people has increased since 1980 s as the use of the source-oriented strategies increased in the retranslation compared to their use in the initial one. For $44.55 \%$ of the items in this category, the retranslator used strategies that preserve the original reference and the sense as the readers do not need any explanations, additions, omissions or substitutions to understand their meanings today. The percentage of these source-oriented strategies for this group of items in the initial translation was only $10.65 \%$.

Table.5. Examples about The Category of 'Material Culture'

\begin{tabular}{|c|c|c|c|}
\hline & ST & TT1 & TT2 \\
\hline Example 1 & $\begin{array}{l}\text { Boutillier took a pack of } \\
\text { Marlboros from his shirt pocket } \\
\text { and stuck one in his mouth. He } \\
\text { offered the pack to Unwin. } \\
\text { "Cigarette?"(King,1986/2017, p.18) }\end{array}$ & $\begin{array}{l}\text { Boutillier cebinden bir } \\
\text { paket çlkardı. Bir sigara } \\
\text { çekip dudaklarının arasına } \\
\text { slkış̦tırdı. Sonra paketi } \\
\text { Unwin'e uzattı. "Sigara? } \\
\text { (King, 1986/Suveren, } 1987 \\
\text { (trans.),p.17) }\end{array}$ & $\begin{array}{l}\text { Boutillier gömlek } \\
\text { cebinden bir paket } \\
\text { Marlboro çıarıp } \\
\text { sigaralardan birini } \\
\text { ağzına yerleştirdi. Paketi } \\
\text { Unwin'e uzattı. "Sigara?" } \\
\text { (King, 1986/Alpar, 2015 } \\
\text { (trans.),p.29) }\end{array}$ \\
\hline Example 2 & $\begin{array}{l}\text { There was a sudden wild impulse } \\
\text { to whip out his Zippo and light it } \\
\text { up... (King, 1986/2017,p.69) }\end{array}$ & $\begin{array}{l}\text { Birdenbire içinden } \\
\text { çakmağını çıkararak bütün } \\
\text { bu kâğıtları yakmak geldi } \\
\text { (King, 1986/Suveren, } 1987 \\
\text { (trans.),p.48) }\end{array}$ & $\begin{array}{l}\text { İçinden Zippo'sunu } \\
\text { çıkarıp bütün belgeleri } \\
\text { yakmak geldi (King, } \\
\text { 1986/Alpar, 2015 } \\
\text { (trans.),p.84) }\end{array}$ \\
\hline
\end{tabular}

The examples in Table. 5 are related to the translation of the brands and products that were categorized in the category of material culture. It can be seen in the first example that the cigarette brand "Marlboro" was not mentioned in the initial translation. Instead of this, the item was referred in general terms as cigarette. The same strategy was observed in the translation of many other brand names of the alcoholic drinks and cigarettes that were mentioned in the original text such as Winston, Pall-Mall, Camel, Dixie,

Adres $\mid$ Address

RumeliDE Dil ve Edebiyat Araşttrmaları Dergisi Osmanağa Mahallesi, Mürver Çiçeği Sokak, No:14/8 Kadıköy - İSTANBUL / TÜRKIYE 34714 e-posta: editor@rumelide.com tel: +90 5057958124, +902167730616

RumeliDE Journal of Language and Literature Studies

Osmanağa Mahallesi, Mürver Çiçeği Sokak, No:14/8

Kadıköy - ISTANBUL / TURKEY 34714

e-mail: editor@rumelide.com

phone: +90 5057958124, +90 2167730616 
Bud, Miller, Narragansett, etc. In the initial translation of the book in 1987, these brand names were either deleted or translated with the strategy of absolute universalization in general terms as "sigara" and "bira". The reason for using such strategies while translating these items during those years can be explained with the socio-cultural context of the receiving society at that particular time period. In line with post-translation studies, it is necessary to understand the social conditions when this initial translation was published and the changes that have taken place in the society after its publication.

In Turkey, until nearly the end of the 1980s, all the manufacturing and distribution of the alcohol and tobacco products was carried out by the state-owned company called TEKEL. There was a strict state control over the sale of the foreign cigarette brands in the country. With 'January, 24 Decisions' in 1980, the country adopted a free market economy policy and it became easier for the foreign brands to enter the domestic market. The monopoly of the state about the production of cigarettes ended especially with an act in 1986 and foreign cigarette brands like Marlboro, Camel and Parliament started to be sold and advertised in the country in the second half of the 80 (Sariyer, 2009).

These socio-cultural developments are significant to understand the translational decisions in the first translation and the retranslation of the book. Since these foreign brands were not sold in the 1980s, the first translator preferred to use target-oriented strategies while translating them. On the other hand, most of these brand names were translated with the strategy of repetition in the retranslation of the book in 2015 .

Another example of this difference in the translation strategies for the brands can be seen in the second example in Table. 5. The trademark of Zippo is well-known in many parts of the world today as a famous American brand. These brands like Zippo, Marlboro, Winston, Ford, Coca Cola are not only associated with the real products but they are also symbolically representative of the American culture. According to Vučetić (2018), the first images that come to mind about America are usually "Coca-Cola, McDonald's, Disneyland, Levi's jeans, the gigantic letters of the Hollywood sign above Los Angeles, or the image of the modern cowboy on a horse from the Marlboro ads" (p.1). Although these appear like stereotypical "materializations", Vučetić (2018) states that "it is precisely by means of these stereotypes, as symbols of the American way of life, that America has constructed and built up its image as it grew into the leading power of the twentieth century (p.1). Accordingly, the process of the increasing consumption of the famous American products and the increasing influence of the American culture went hand in hand in many parts of the world.

Considering this relationship between the actual consumption of these products and the cultural influence, it can be seen in the example that the brand Zippo was translated as "çakmak" (lighter) by using the strategy of absolute universalization in the initial translation of the book in 1987. On the other hand, the item was translated by mentioning the name of the brand as Zippo using the strategy of repetition in the retranslation of the book in 2015 .

As a matter of fact, it can be claimed that the book is full of these brand names and products since this is one of the cultural categories with the highest number of CSIs detected in the source text. In total, $73.55 \%$ of the brand names and trademarks that were mentioned in the original book were translated with source-oriented strategies in the retranslation whereas only $4.46 \%$ of these items were translated with source-oriented strategies in the initial translation. In addition, $65.41 \%$ of such items were not translated at all in the first translation as they appeared in the omitted parts and sentences of the book or they were deleted as individual items while translating the sentences.

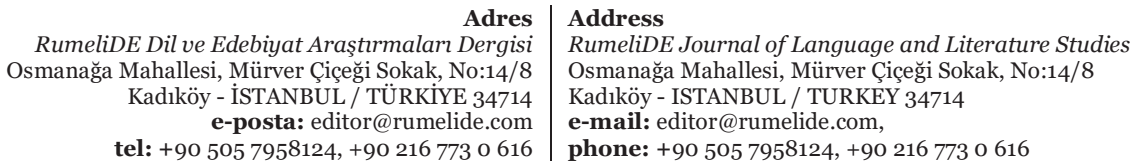


1112 / RumeliDE Journal of Language and Literature Studies 2022.26 (February)

Towards an understanding of post-translation studies: A comparative analysis of cultural transfer in the rewritings of popular literature / D. Özbek \& A. S. Söylemez (pp. 1098-1116)

Table.6. Examples about The Category of 'Education'

\begin{tabular}{|c|c|c|c|}
\hline & ST & TT1 & TT2 \\
\hline Example 1 & $\begin{array}{l}\text { Bill was good at reading and } \\
\text { writing, but even at his age } \\
\text { George was wise enough to } \\
\text { know that wasn't the only } \\
\text { reason why Bill got all A's on } \\
\text { his report cards, or why his } \\
\text { teachers liked his } \\
\text { compositions so well. } \\
\text { (King,1986/2017,p.5) }\end{array}$ & $\begin{array}{l}\text { Bill okuma ve yazma } \\
\text { konusunda başarılıydı. Ama } \\
\text { George, Bill'in o yaşta bile } \\
\text { karnesinin pekiyilerle } \\
\text { dolmasının ya da } \\
\text { öğretmenlerinin } \\
\text { kompozisyonlarını çok } \\
\text { beğenmelerinin tek nedeninin } \\
\text { bu olmadığını anlıyordu } \\
\text { (King,1986/Suveren,1987 } \\
\text { (trans.),p.9) }\end{array}$ & $\begin{array}{l}\text { Ağabeyi okuma ve yazma } \\
\text { konusunda çok yetenekliydi } \\
\text { ama George henüz küçük } \\
\text { bir çocuk olmasına karşın, } \\
\text { Bill’’n bütün derslerden A } \\
\text { almasının yegane nedeninin } \\
\text { bu olmadığını bilecek kadar } \\
\text { akıllıydı } \\
\text { (King,1986/Alpar,2015 } \\
\text { (trans.),p.13) }\end{array}$ \\
\hline Example 2 & $\begin{array}{l}\text { Played football for the Derry } \\
\text { Tigers. Honor Roll student } \\
\text { (King,1986/2017,p.448) }\end{array}$ & $\begin{array}{l}\text { Çok çalışkanmış, okul futbol } \\
\text { takımında oynuyormuş } \\
\text { (King,1986/Suveren,1987 } \\
\text { (trans.),p.196) }\end{array}$ & $\begin{array}{l}\text { Derry Kaplanları takımında } \\
\text { Amerikan futbolu oynamış. } \\
\text { Onur listesindeki } \\
\text { öğrencilerden } \\
\text { (King,1986/Alpar,2015 } \\
\text { (trans.),p.484) }\end{array}$ \\
\hline
\end{tabular}

The examples in Table.6 illustrate the influence of the source culture on the receiving society in terms of the education system since the publication of the first translation. It should be pointed out that until the last two decades, grading systems of the US and Turkey were different in many respects. Turkish people were not so familiar with the grades indicated by the letters from A to F. Instead, grading was based on the numerical scores only or it was based on categories like 'pekiyi' (very good), 'iyi' (good), etc. However, especially after the increase in the schools where medium of instruction is English, US grading system started to be used in many universities in Turkey. As a result, people in the receiving society became more familiar with what these grades represented. Thus, strategies that were used by the translators in the first example can be considered as a reflection of these changing conditions in the country. While the grade "A" was translated as "pekiyi" in the initial translation, it was translated as "A" by using the strategy of repetition. If it had been translated as it is with the strategy of repetition in the initial translation as well, it could have been confusing for the readers during those years to comprehend the level of success indicated with that letter.

A similar strategy was observed in the second example, as well. The item "honor roll student" was translated as "çok çalışkanmış" (he was very hardworking) in the initial translation while it was translated as "onur listesindeki öğrencilerden" (honor roll student) in the retranslation of the book. This difference in the translation strategies can be explained with the increasing familiarity of the educational concepts for the readers in time. The first translator of the book preferred to use a target-oriented strategy for the item and provided a general description of it as the readers were not so familiar with the concept of 'honor roll student' during those years. On the other hand, the item became increasingly familiar for the readers and the retranslator of the book did not need to provide any explanations for it.

In general, it was found out that the items in relation to the educational system of the source culture were predominantly translated with target-oriented strategies in the first translation whereas they were mostly translated with the source-oriented strategies in the retranslation of the book.

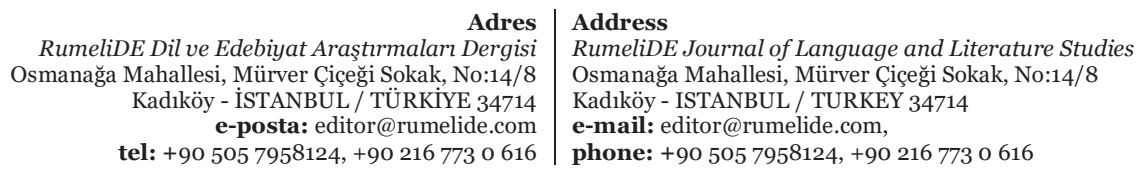




\section{Conclusion}

Due to the rapid technological advances and dynamics of globalism since 1980 s, the socio-cultural functions of translations have changed in many respects. Today, publication and distribution of translations have become increasingly dependent on the needs of the local and international markets. As Cronin (2003) points out, "the shortened time-scale of the post-Fordist economy has profoundly affected the whole industry of publishing, which in the English speaking world has been transformed by a whole series of mergers and acquisitions throughout the 1980 os and 1990s" (p.120). Such developments during these years led to a remarkable growth of the book publishing industry as well as fast and easy distribution of the books in many parts of the world. As a consequence of this process, translations could reach people from different cultures in a very short time and turned into 'products' more than ever. It can be claimed that, in today's global world, "everything turns out to be a replica, a simulacrum, a copy of a limited set of economically and culturally powerful originals" (Cronin, 2003, p.129).

Concerning these developments about the nature and the function of translations in the modern times, it becomes vital to understand what these translations convey to different parts of the world simultaneously as cultural products. After determining this need in translation studies, Edwin Gentzler (2017) put forward a framework with the name "post-translation studies" which focuses on the sociocultural conditions in the receiving society both before and after the translations were published.

In line with this framework, in this article, the initial translation and the retranslation of Stephen King's $I T$ in 1987 and 2015 were compared in terms of the representation of the culture specific items. Both of these translations were published by the same publisher as an indication of the changing expectations of the readers in time. Through this comparison, it was aimed to understand the socio-cultural conditions that could be instrumental in the translators' decisions in different time periods and to trace the influence of the source culture on the receiving society in time.

For the categorization of the CSIs that were detected in the novel, Pavlovic and Poslek's (1998) model was used with an additional category to include the items about the description of people. Translation strategies for these items were categorized according to Aixela's (1996) categorization. These categories were also labeled as "source-oriented" and "target-oriented" in terms of preserving the 'foreign essence' of the item concerning its meaning. As a result of the analysis, it was found out that while target-oriented strategies were mostly used in the initial translation for the CSIs in the original book, retranslator of the novel predominantly preferred source-oriented strategies for the same items. In addition, it was observed that the familiarity of the items for the readers was a determining factor on the translational decisions. Both the first translator and the retranslator used source-oriented strategies for the familiar items and they used target-oriented strategies for the unfamiliar items during the time the translations were produced. Thus, the increase in the use of the source-oriented strategies in the retranslation indicated an increase in the familiarity of the American cultural elements for the Turkish readers since 1980 .

These results illustrate that, in the age of post-translation studies, it is important to evaluate the pretranslation and post-translation conditions of the societies in order to understand the translational decisions and the socio-cultural functions of the translated texts. This study was designed in a way to contribute to the field in terms of how to conduct analyses that reflect the basic arguments of posttranslation studies. Based on this approach, translational differences between two different rewritings of the same novel were analyzed with reference to the changes in the socio-cultural conditions of the

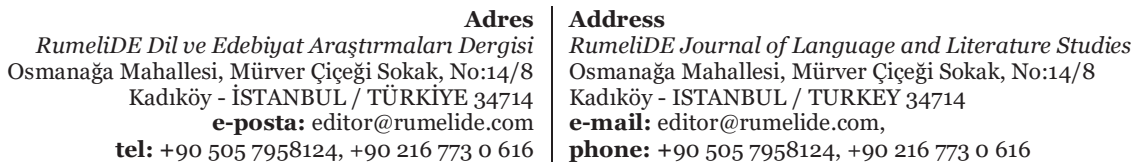


receiving society rather than depending on explanations on the textual level. Such analyses of posttranslation studies can yield insights in relation to the dynamics of the target culture, influence of the source culture in time and the changing expectations of the readers.

\section{References}

Aixelá, J. F. (1996). Culture-Specific Items in Translation. In R. Álvarez and M. Carmen-África Vidal (Eds.), Translation, Power, Subversion (pp.52-78). Clevedon: Multinlingual.

Bali, R. N. (2002). Tarz-ı Hayattan Life Style'a: Yeni Seçkinler, Yeni Mekanlar, Yeni Yaşamlar. Istanbul: İletişim Yayınları.

Bassnett, S. (1980). Translation studies. London: Methuen.

Bassnet, S. \& Lefevere, A. (1998). Constructing Cultures: Essays on Literary Translation Topics in Translation. Clevedon \& Philadelphia: Multilingual Matters.

Bassnett, S. (2007). Culture and Translation. In P. Kuhiwczak and K. Littau (Eds.), A Companion to Translation Studies (pp. 13-23). Clevedon: Multilingual Matters.

Baumgarten, S. \& Cornellà-Detrell, J. (2018). Translation and the Economies of Power. In S. Baumgarten \& J. Cornellà-Detrell (Eds.), Translation and Global Spaces of Power. Bristol: Multilingual Matters.

Bolton, K. \& Olsson, J. (2010). Media, Popular Culture and The American Century. Sweden: Fälth \& Hässler.

Boughton, J.M. (2001). Silent Revolution: Monetary Fund, 1979-1989. USA: International Monetary Fund.

Büken, G. (2001). Amerikan Popüler Kültürünün Türkiye'de Yayılışına Karşı Tepkisel Düşünceler. Doğu Batı, (15), 41-51.

Conversi, D. (2010). The Limits of Cultural Globalisation? Journal of Critical Globalisation, (3), 36-59.

Cronin, M. (2003). Translation and Globalization. London \&New York: Routledge.

Even-Zohar, I. (1979). Polysystem Theory. Poetics Today, 1(1/2), 287-310.

Even-Zohar, I. (1990). Polysystem Studies. Poetics Today International Journal for Theory and Analysis of Literature and Communication, 11(1), 1-268.

Even-Zohar, I. (2002). The Making of Culture Repertoire and the Role of Transfer. In S. Paker (Ed.), Translations: (Re)shaping of Literature and Culture (pp.166-174). Istanbul: Boğaziçi University Press.

Gentzler, E. (2017). Translation and Rewriting in the Age of Post- Translation Studies. London\& New York: Routledge.

Gökçen, A. (2013). Cumhuriyetten Günümüze Türkiye'de İktisat Politikaları ve Ekonomik Gelişme. In M. Zencirkıran (Ed.), Dünden Bugüne Türkiye’nin Toplumsal Yapısı (pp.213-242). Bursa:Dora.

Gürbilek, N. (2016). Vitrinde Yaşamak: 1980’lerin Kültürel İklimi. (8th ed.) Istanbul: Metis (Original work published 1992)

Güzelsarı, S. (2007). Küresel Kapitalizm ve Devletin Dönüşümü.Türkiye'de Mali İdarede Yeniden Yapllanma [Doctoral dissertation, Ankara University, Institute of Social Sciences]. Council of Higher Education Thesis Center. https://tez.yok.gov.tr/

Hermans, T. (1985). The Manipulation of Literature: Studies in Literary Translation. London: Croom Helm.

Holt, J. (2001). In Deregulation We Trust: The Synergy of Politics and Industry in Reagan-Era Hollywood. Film Quarterly, 55(2), 22-29. Retrieved from https:// www.jstor.org

Index Translationum. (2019). Top 50 Most Translated Authors. Retrieved from http://www.unesco.org

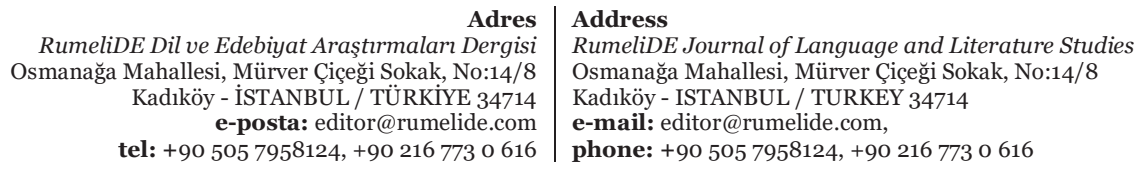


King, S. (1987). O. (G. Suveren, Trans.). Istanbul: Altın Kitaplar Yayınevi. (Original work published 1986)

King, S. (2015). O. (O. Alpar, Trans.). Istanbul: Altın Kitaplar Yayınevi. (Original work published 1986)

King, S. (2017). IT. London: Hodder (Original work published 1986)

Köse, A. (2016). Geleneksel İle Modern Arasındaki Kültürel Boşluk: 8o'lerdeki Toplumsal Değişimi Mizah Üzerinden Okumak. Millî Folklor, 28(111),116-135.

Lefevere, A. (1992). Translation, Rewriting and the Manipulation of Literary Fame. London: Routledge.

Lefevere, A. (1998). Chinese and Western Thinking on Translation. In S. Bassnett \& A. Lefevere (Eds.), Constructing Cultures: Essays on Literary Translation (pp.12-25). Philadelphia: Multilingual.

Pavlovic, N. \& Poslek, D. (1998). British and Croatian Culture-Specific Concepts in Translation. In J. Ciglar-Zanic (Ed.), British Cultural Studies: Cross-Cultural Challenges (pp.157-168). Zagreb: The British Council Croatia.

Pawling, C. (1984). Popular Fiction and Social Change. London: MacMillan Press.

Sarıyer, N. (2009). Sigara İçen Gençler Arasında Marka Tercihi Üzerine Bir Araştırma. Marmara Üniversitesi Sosyal Bilimler Enstitüsü Dergisi, 8 (31), 145-155.

Sassen,S. (1996). Losing Control: Sovereignty in an Age of Globalization. New York: ColumbiaUniversity Press. Retrieved from: https://www.researchgate.net/publication

Sever, M. (2019). 1980 Sonrası Türkiye'de Kültürel ve Toplumsal Değişme. Uluslararası Halkbilimi Araştırmaları Dergisi. 2(3), 1-10.

Sönmez,S. (2008). 1980 Sonrası Türkiye'deki Sosyo-Politik Ve Ekonomik Değişimlerin 200o'li Yıllara Yansımaları [Master's thesis, Afyon Kocatepe University]. Council of Higher Education Thesis Center. https://tez.yok.gov.tr/

Snell-Hornby, M. (2006). The Turns of Translation Studies. Amsterdam\& Philadelphia: John Benjamins Publishing Company.

Spignesi, S.J. (2001). The Essential Stephen King. NJ: New Page Books.

Strange, S. (1996). The Retreat of the State: The Diffusion of Power in the World Economy. Cambridge: Cambridge University Press.

Şahin, M.C. (2005). Türkiye'de Gençliğin Toplumsal Kimliği ve Popüler Tüketim Kültürü. Gazi Eğitim Fakültesi Dergisi. 25 (2), 157-181.

Tellan, D.ö. (2008). Tüketimin Karşı Devrimi: Türkiye'de 1980 Sonrası Uygulanan İktisat Politikalarının Toplumsal Sonuçlarına Eleştirel Bir Bakış. Ekonomik Yaklaşim. 19(67), 1-19.

Thompson, G. (2007). American Culture in the 1980s. Edinburgh: Edinburgh University Press.

Toury, G. (1985). A Rationale for Descriptive Translation Studies. In T. Hermans (Ed.), The Manipulation of Literature (pp.16-41). London\& Sydney: Croom Helm.

Toury, G. (1995). Descriptive Translation Studies and Beyond. Amsterdam\& Philadelphia: John Benjamins

Toury, G. (2004). The Nature and Role of Norms. In L. Venuti (Ed.), The Translation Studies Reader (pp.198-211). London\&New York: Routledge (Original work published 1978)

Toury, G .(2005). Enhancing Cultural Changes by Means of Fictitious Translations. In E. Hung (Ed.), Translation and Cultural Change (pp.3-17). Amsterdam\& Philadelphia: John Benjamins Publishing Company.

Uçkaç, A. (2010). Türkiye'de Neoliberal Ekonomi Politikaları ve Sosyo-Ekonomik Yansımaları. Maliye Dergisi, (158), 422-430.

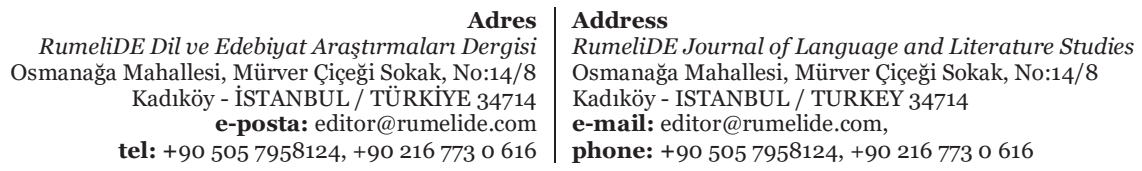


Venuti, L. (1995). The Translator's Invisibility: A History of Translation. London and New York: Routledge.

Venuti, L. (1998). The Scandals of Translation: Towards an Ethics of Difference. London: Routledge.

Venuti, L. (2012). World Literature and Translation Studies. In T. D’haen, D. Damrosch \& D. Kadir. (Eds.), The Routledge Companion to World Literature (pp.180-193). Oxon: Routledge.

Vučetić, R. (2018). Coca-Cola Socialism. Americanization of Yugoslav Culture in the Sixties. (J, Cox. Trans.). Budapest \& New York: Central European University Press.

Wood, R. (2011). Stephen King: A Literary Companion. North Carolina\& London: McFarland \& Company, Inc. Publishers.

Zeytinoğlu, F., Uydaci, M., Akay, E., Değerli, B. \& Yerden, N. (2016). İstanbul'daki Alışveriş Merkezleri Üzerine Bir Araştırma: Kümeleme Analizi. Social Sciences Research Journal, 5 (1), 1111-128 